DOI: $10.17805 /$ zpu.2015.2.36

\title{
Свобода и отчаяние в поэзии Ирины Кнорринг
}

\author{
В. А. СоколовА \\ (ЛИТЕРАТУРНЫЙ ИНСТИТУТ ИМ. А. М. ГОРЬКОГО, Г. МОСКВА)
}

В статье исследуется восприятие связи свободы и отчаяния в литературе русского зарубежья на примере поэзии Ирины Кнорринг (1906-1943), представителя младшего поколения первой волны русской эмиграции. Связь свободы и отчаяния в ее творчестве рассматривается с двух сторон: как непосредственно личное восприятие, исходящее из собственного беженского и эмигрантского опыта, и как явление, отражающее восприятие, свойственное ее поколению в целом. В свою очередь, интерес ее современников к этой проблеме дается в контексте традиции понимания свободы в русской литературе.

В статье прослеживается связь творчества Ирины Кнорринг, формально не входившей в поэтические группировки, с поэзией «парижской ноты», явлением, сформированным критикой Г. Адамовича и атмосферой поэтического сборника «Розы» Г. Иванова. Упоминается общая для них «дневниковая» манера письма, а для передачи интонационного родства рассматриваются отдельные произведения Кнорринг.

Разбираются два стихотворения Кнорринг, первое из которых «Быть странником, без жалоб и без стонов...» (1928) относится к периоду развития и становления ее поэтического дара, а второе «Шумный ветер деревья ломит...»(1940) - к заключительному периоду ее жизни. Их исследование позволяет проследить развитие характерных образов и эволюцию взглядов автора, связанную с усилением ощущения трагичности мира и существования человека-изгнанника в нем. В процессе анализа выделяются образы в своем употреблении, свойственные исключительно индивидуальному лексическому словарю поэзии Кнорринг. Также затрагиваются важнейшие для Кнорринг темы утраченной родины, России, безнадежного эмигрантского существования, посредством чего демонстрируется и ее собственный поэтический мир, и включенность Ирины Кнорринг в общую литературную ситуацию русского зарубежья.

Ключевые слова: русская эмиграция, Ирина Кнорринг, «парижская нота», русская литература.

\section{BВEАЕНИЕ}

Dусский поэт Ирина Николаевна Кнорринг (1906-1943), будучи представителем младшего поколения «первой волны» эмиграции, или «незамеченного» поколения (Варшавский, 1956), глубоко восприняла и отразила в своем творчестве трагедию русской эмиграции. По словам ее современника Г. П. Струве, поэзия Кнорринг «едва ли не самая грустная во всей зарубежной литературе» (Струве, 1996: 238). Аля ее поколения, росшего на чужой культурной почве, характерны мотивы тоски и одиночества, а понятие свободы является одним из основных в творчестве и мировосприятии, сочетая в себе индивидуальные впечатления и традицию осмысления свободы в русской литературе.

Свободолюбивая лирика Байрона вошла в русскую литературу еще с именами А. С. Пушкина и М. Ю. Аермонтова и дала пищу для последующего поэтического диалога и раскрытия понятия свободы. Понятие это явилось одной из важнейших категорий для культуры рубежа XIX-XX вв. Свое дальнейшее развитие оно нашло в литературе русского зарубежья, а особенно - в «парижской ноте», которая представляла собой организационно неоформленную школу, ориентирующуюся на поэтические установки Г. Адамовича и существовавшую в Париже в конце 1920-х - 1930-е годы.

Наиболее глубоко его разработал в своих статьях Г. Адамович, идейный вдохновитель «ноты». Он высоко ценил творчество Байрона и говорил, что его имя - «одно из дорогих России имен» (Адамович, 1924: 2). 
Ирина Кнорринг, формально не входя в литературные группировки, интонационно все же тяготела к поэзии «ноты». Стоит отметить, что, говоря о широте влияния «ноты», О. А. Коростелев отмечает: «В строгом смысле слова к “парижской ноте” можно отнести кроме самого Адамовича только А. Штейгера и $\Lambda$. Червинскую. Но реальное воздействие “ноты Адамовича" было гораздо шире, следы ее влияния можно найти у многих поэтов эмиграции, в том числе и принадлежавших к оппозиционным лагерям» (Коростелев, 2002: 13).

У истоков этого нового мироощущения стоял поэтический сборник «Розы» (1931) Г. Иванова, одного из предшественников «ноты». Характерно, что оба, и Г. Иванов, и Г. Адамович, высоко ценили стихи Кнорринг. Так, Г. Адамович отмечах, что «у Ирины Кнорринг бесспорно есть поэтическое дарование, видна у нее и литературная выучка» (Адамович, 1931: 3), а Г. Иванов назвал ее «не очень сильным, но настоящим поэтом» (Иванов, 1993: 585).

\section{ОТ РАННЕЙ ПОЭЗИИ К ЗРЕАОЙ}

Близость мироощущения Кнорринг с «парижской нотой» отражает дневниковая манера письма, свойственная «парижанам». Но важным при этом является и тот факт, что «дневниковость» стиля Кнорринг проявилась еще в детстве, во время «бега» семьи по югу России, насыщенного событиями и заставившего ее фиксировать каждое мгновение в дневнике и стихах.

В ее раннем творчестве ощутимо романтическое влияние, а вместе с тем мотивы тоски и одиночества. Примером может служить стихотворение 1920 г., написанное во время стоянки в Константинополе корабля, увозившего ее из Крыма:

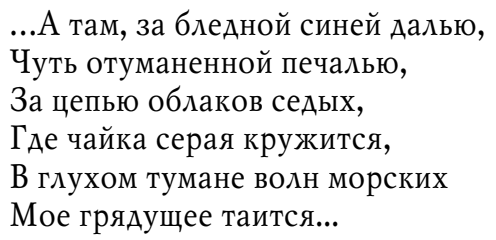

(Кнорринг, 1993: 12)

Свобода в этом юношеском стихотворении еще подразумевает некую надежду на будущее, хотя и весьма сомнительную.

Постепенно с усилением трагического мировосприятия в поэзии Кнорринг глубже будет осознаваться бедствие революции и эмиграции, а образ покинутой Родины станет одним из основных. Переживание этой потери и собственной бесприютности сблизит в ее творчестве понятия свободы и изгнанничества.

Чтобы показать это, нами взяты два стихотворения Кнорринг - «Быть странником, без жалоб и без стонов...» (1928) и «Шумный ветер деревья ломит...» (1940).

Первое из них относится к годам становления и активного развития ее поэтического творчества, второе представляет собой позднюю лирику заключительного этапа жизни.

Быть странником, без жалоб и без стонов,

Пьянеть простором незнакомых мест,

Увидеть новый мир в окно вагона, -

Ведь это никогда не надоест.

Теряя день за днем, и год за годом,

Иишь впечатленьями разбогатеть. 
Июбить одну бессмертную свободу

И никогда о прошлом не жалеть.

Всю жизнь идти дорогой незнакомой

По зарослям, пустыням, городам.

И жить одной, одной тоской о доме,

О нежности, не бывшей никогда.

(Кнорринг, 1931: 12)

В данном стихотворении с первой строки образы изгнанника и существование вне родины даются как само собой разумеющиеся явления жизни. В поэзии Кнорринг эти образы занимают важнейшее место. Вместе с тем видна попытка принятия такой жизни «без жалоб и без стонов», отрешения от прошлого с помощью «опьянения» себя новыми впечатлениями. Однако заранее видна и бессмысленность подобного решения, которая еще полнее раскроется к концу стихотворения. Разрушение заданного настроя происходит буквально в следующей строке, когда на «новый мир» предлагается смотреть из окна вагона. Вагон в поэзии Кнорринг соотносится с образом поезАа, который устойчиво ассоциируется с беженскими годами, революцией и изгнанием. В попытке уйти от прошлого Кнорринг снова возвращается к нему. Образ окна не менее интересен, поскольку связан с восприятием Кнорринг своей жизни как неудавшейся, где окно - единственный выход во внешний мир. Образ окна тесно связан у Кнорринг с образами глаз и взгляда, указывая на общение, в отличие от образа двери, который несет в себе функцию разделения людей.

В следующей строфе речь идет о жизни как о времени, и главный акцент сделан на слове «терять». Годы и дни проходят мимо, время само по себе - потеря. «Бессмертная свобода» здесь воспринимается и глобально, с отсылкой к традиции, и индивидуально, как собственная доля эмигранта. Стремление, о котором говорись иносказательно, теперь сформулировано четко: «и никогда о прошлом не жалеть». Однако ключевое слово здесь - «прошлое». Оно утрачено вместе с родиной, попытка забыть его говорит как раз об обратном - боли, существующей в настоящем. Подобным приемом доказательства от противного часто пользуется в своей поэзии Г. Иванов, чье влияние на «парижскую ноту» сложно недооценить.

Эти выводы подтверждаются объединением образов жизни и дороги в следующих строках, что в очередной раз подчеркивает мысль Кнорринг об изгнании, отсутствии дома и невозможности его обретения для нее, поскольку прежний дом, родина, уничтожены и недостижимы (см.: Соколова, 2014). Перечисление «заросли, пустыни, города» представляет собой воспоминание о бегстве и жизни в Африке. В итоге в завершающих строках стихотворения Кнорринг приходит к тому, что отрицала и от чего стремилась уйти - «И жить одной, одной тоской о доме // О нежности не бывшей никогда». Слово «никогда»- одно из самых распространенных у Кнорринг, оно несет в себе глубокую тоску и боль изгнанника, как и использующееся рядом с ним отрицание - «не бывшей» нежности - символа несбыточных надежд и мечтаний.

\section{ПРЕАСМЕРТНАЯ ПОЭЗИЯ КНОРРИНГ}

Второе стихотворение «Шумный ветер деревья ломит...» написано автором за несколько лет до смерти.

Шумный ветер деревья ломит,

Резкий ветер с холодных полей. 
Мы не спим в нашем маленьком доме,

Будто в бурю на корабле.

Наверху прикорнули дети,

Аверь во тьму заперта на ключ,

И шумит оголтелый ветер,

Нагоняя обрывки туч.

Напряженны и строги лица:

Все испробованы пути,

Все равно - никуда не скрыться,

От отчаянья не уйти!

За окном ничего не видно.

Черный ветер шатает дом.

- Как бессильны мы, как беззащитны

В урагане, в жизни, во всем.

Одиноко, холодно, сыро.

Стынет чайник на длинном столе.

Будто выброшенные из мира

На потерянном корабле...

(Кнорринг, 1993: 114).

В тексте заметно значительное усиление переживаний одиночества, боли и тоски. Чувства, что вызывали сомнения и размышления в предыдущем стихотворении, здесь отлились во всей своей полноте.

Один из наиболее распространенных образов поэзии Кнорринг - образ ветра, акмеистически передающий сознание героини через внешний мир. В данном стихотворении характеристики ветра, «шумный», «резкий», сразу формируют общую атмосферу ненастья, дополненного упоминанием «холодных полей». Это чувство передается людям, находящимся в доме. Аом, как и прежде, воспринимается Кнорринг как ненастоящий и сравнивается с кораблем, попавшим в бурю, функция защиты, которую он должен выполнять, весьма сомнительна. Сравнение с кораблем навеяно бушующей непогодой и возвращает Кнорринг к воспоминаниям о днях, проведенных ею на корабле врангелевской эскадры после отплытия из Севастополя.

В следующей строфе упоминаются дети. Образ ребенка у Кнорринг - один из главнейших, а тема любви и материнства является одной из основных. Ребенок, сын это то, что дает ей силы жить, противостоять тьме и смерти. Образ тьмы, темноты, окружившей дом, также часто используется Кнорринг. Он служит как для характеристики внешнего мира, так и для передачи состояния души героини.

Усиление бури отражается в эпитетах, описывающих ветер. Аица людей, находящихся внутри дома, «напряженны и строги», это спокойствие знания, объясняющее следующие строки: «Все равно - никуда не скрыться». Они уже сталкивались с подобной бедой. Испробованные пути - отсылка к событиям революции, через которые они прошли. Слово «никуда», как и «никогда», весьма характерно для Кнорринг. «От отчаянья не уйти!» - кульминационная точка стихотворения. Не зря использован знак восклицания, нехарактерный для приглушенной интонации поэзии Кнорринг. Отчаяние здесь достигает своего пика.

За окном, соотносимым с глазами человека, «ничего не видно». Ветер сливается с тьмой, получая әпитет «черный». Его сила - это уже сила века, способного расша- 
тать и свернуть дом, родину, Россию - понятия, между которыми Кнорринг ставит знак равенства. Бессилие людей на фоне этой катастрофы стилистически подчеркивается повторами: «Как бессильны мы, как беззащитны // В урагане, в жизни, во всем». Происходит объединение образов непогоды, событий из прошлого и глобального чувства беспомощности человека перед внешним миром. «Одиноко, холодно, сыро» - экзистенциальные характеристики человеческого существования. «Чайник» как предмет быта возвращает взгляд от глобального к частному, боль отдельного человека отражает в себе мировые процессы. «Будто выброшенные из мира // На потерянном корабле»- строки, которые опять отсылают к началу эмигрантского пути. Происходит слияние настоящего с прошлым, момент переживаемой непогоды и момент покидания Родины сливаются в одно вневременное пространство. И вечное одиночество и неприкаянность в этом холодном эфире звучат у Кнорринг вполне «по-Ивановски», в согласии со всей «парижской нотой».

\section{ЗАКАЮЧЕНИЕ}

Восприятие свободы в ее позднем творчестве превратилось в своеобразную «выброшенность из мира» и подчас оказывается тесно связано с мотивами тоски, одиночества и смерти.

Таким образом, рассматривая понятия свободы и отчаяния как основополагающие Аля поэзии «парижской ноты» в целом, можно говорить и о творческом вкладе Ирины Кнорринг, внесенном в раскрытие этой темы, волновавшей Г. Адамовича и Г. Иванова и составившей очередной этап в развитии и осмыслении категории свободы в русской литературе.

\section{СПИСОК АИТЕРАТУРЫ}

Адамович, Г. (1924) Последний мировой поэт // Звено (газета). № 64. 21 апреля. С. 2.

Адамович, Г. (1931) Аитературные заметки // Последние новости (газета). № 3690.30 апреля. С. 3.

Варшавский, В. С. (1956) Незамеченное поколение. Нью-Йорк : Изд-во имени Чехова. 387 с.

Иванов, Г. В. (1993) Поэзия и поэты // Иванов, Г. В. Собр. соч. : в 3 т. М. : Согласие. Т. 3. Мемуары. Аитературная критика. 720 с. С. 583-587.

Кнорринг, И. (1931) Стихи о себе. Париж : Тип. «Паскаль». 60 с.

Кнорринг, И. (1993) После всего: Стихи 1920-1942 гг. Алма-Ата : Вариант. 126 с.

Коростелев, О. А. (2002) Пафос свободы. Аитературная критика русской эмиграции за полвека (1920-1970) // Критика русского зарубежья : в 2 ч. М. : Олимп ; АСТ. Ч. 1. 470 с. С. 3-35.

Соколова, В. А. (2014) Эволюция тем России и скитаний в поэзии Ирины Кнорринг // Историческое образование. № 3 (3). С. 147-158.

Струве, Г. П. (1996) Русская литература в изгнании. 3-е изд., испр. и доп. Париж : ҮМСАPress ; М. : Русский Путь. 448 с.

Аата поступления: 15.01.2015 2.

\section{FREEDOM AND DESPAIR IN THE POETRY \\ OF IRINA KNORRING \\ V. A. SOKOLOVA \\ (MAXIM GORKY LITERATURE INSTITUTE, MOSCOW)}

The article looks at the themes of freedom and despair in Russian émigré literature, namely the poetry of Irina Knorring (1906-1943), who belonged to the junior generation of the Russian emigration's first wave. The links between the concepts of despair and freedom in her texts were based both on her personal experience of a refugee, and on a perception typical for the entire generation. The 
interest Knorring's contemporaries took in these motives is shown here as rooted in Russian literature since the days of Alexander Pushkin, Mikhail Lermontov and other Russian writers, who followed and adopted the traditions established by George Gordon Byron.

We trace the link between the poetry of Irina Knorring (who never belonged to any poetic group) and that of the "Paris Note" - a poetic phenomenon shaped by Georgy Adamovich's literary criticism and the poetic atmosphere set by "Roses", a collection of poems by Georgy Ivanov. All of these shared the "diary" style of writing. To find elements of intonational affinity, we have analyzed two poems by Irina Knorring.

One of them - "Byt' strannikom, bez zhalob i bez stonov..." ("To be a wanderer and never plea or groan...", 1928), is an example of the poet's early work, and the other, "Shumnyi veter derev'ia lomit..." ("A stormy wind is felling trees...", 1940) was written late in her life. This choice helps us trace the evolution of both poetic creativity and opinions of Irina Knorring. The main motives of her poetry were that of losing homeland, life in Russia and hopeless émigré existence. By analyzing these motives, we can have a better grasp of Irina Knorring's poetic world and her place in the literature of Russian emigration.

Keywords: Russian emigration, Irina Knorring, "Paris Note", Russian literature.

\section{REFERENCES}

Adamovich, G. (1924) Poslednii mirovoi poet [The last world poet]. Zveno, no. 64, April 21, p. 2. (In Russ.).

Adamovich, G. (1931) Literaturnye zametki [Notes on literature]. Poslednie novosti, no. 3690, April 30, p. 3. (In Russ.).

Varshavskii, V.S. (1956) Nezamechennoe pokolenie [The unnoticed generation]. New York, Chekhov Publishing House. 387 p. (In Russ.)

Ivanov, G. V. (1993) Poeziia i poety [Poetry and poets]. In: Ivanov, G. V. Sobranie sochinenii [Works] : in 3 vols. Moscow, Soglasie Publ. Vol. 3: Memuary. Literaturnaia kritika [Memoirs. Literary criticism]. 720 p. Pp. 583-587. (In Russ.). Russ.).

Knorring, I. (1931) Stikbi o sebe [Poems on myself]. Paris, Paskal' Printing House. 60 p. (In

Knorring, I. (1993) Posle vsego: Stikbi 1920-1942 gg. [After everything: Poems 1920-1942]. Alma-Ata, Variant Publ. 126 p. (In Russ.).

Korostelev, O. A. (2002) Pafos svobody. Literaturnaia kritika russkoi emigratsii za polveka (1920-1970) [The pathos of freedom. Literary criticism of Russian emigration for half a century (1920-1970)]. In: Kritika russkogo zarubezb'ia [Criticism of the Russian emigre community] : in 2 vols. Moscow, Olimp Publ. ; AST Publ. Vol. 1. 470 p. Pp. 3-35. (In Russ.).

Sokolova, V. A. (2014) Evoliutsia tem Rossii i skitanii v poezii Iriny Knorring [The evolution of the themes of Russia and wandering in the poetry of Irina Knorring]. Istoricheskoie obrazovanie, no. 3 (3), pp. 147-158. (In Russ.).

Struve, G. P. (1996) Russkaia literatura v izgnanii [Russian literature in exile]. 3rd edn., revised and enlarged. Paris, YMCA-Press ; Moscow, Russkii Put' Publ. 448 p. (In Russ.).

Submission date: 15.01.2015.

Соколова Вера Александровна - соискатель кафедры новейшей русской литературы Аитературного института им. А. М. Горького. Адрес: 123104, Россия, г. Москва, Тверской б-р, д. 25. Тел.: +7 (495) 694-06-62. Эл. адрес: sokolova-vera@yandex.ru. Научный руководитель - канд. филол. наук, доц. С. Р. Федякин.

Sokolova Vera Aleksandrovna, Applicant, Department of Contemporary Russian Literature, Maxim Gorky Literature Institute. Postal address: 25 Tverskoi Blvd, 123104 Moscow, Russian Federation. Tel.: +7 (495) 694-06-62. E-mail: sokolova-vera@yandex.ru Research advisor: Candidate of Philology, Associate Professor S. R. Fediakin. 